\title{
Sintesis Tiga Peptida Bergugus Pelindung sebagai Prekursor Komponen Vaksin Influenza Universal
}

\author{
Toto Subroto*,Ari Hardianto, Abdul Alim Kahari, dan Tika Pradnjaparamita \\ Jurusan Kimia Fakultas Matematika dan Ilmu Pengetahuan Alam Universitas Padjadjaran \\ Jl. Raya Bandung-Sumedang km. 21 Jatinangor-Sumedang 45363
}

Diterima 11-12-2012Ｄisetujui 25-11-2013

\begin{abstract}
Current highly effective conventional vaccine to halt the spread of bird flu has not been invented yet because of susceptible mutation of influenza virus. In spite of undergoing mutation which causes the amino acid sequence change, influenza viruses maintain conservation at ectodomain of M2 protein, especially M2e(2-16) (SLLTEVETPIRNEW). The use of conserved epitope M2e(2-16) in epitope-based vaccine potentially produces universal influenza vaccine. In designing epitope-based vaccine, the M2e(2-16) needs to be coupled with T helper epitope, P25, which is subsequently mentioned as M2e(2-16)-K-P25 (SLLTEVETPIRNEWGKKKL IPNASLIENCTKAEL). The M2e(2-16)-K-P25 was synthesized using convergent solid phase peptide synthesis strategy because of the size of the sequence. In this strategy, four peptide precursors of M2e(2-16)-K-P25; SLLTEVETP(F1), IRNEWGK (F2), KLIPNASLI (F3), and ENCTKAEL(F4); were synthesized in advance. After the precursors ready, coupling reaction was performed to obtain M2e(2-16)-K-P25. In the previous research, F3 has been obtained in high purity through Fmoc/tBu solid phase peptide synthesis method. In this conducted research, the three remaining precursors; F1, F2, and F4; were synthesized by the same method. Each peptide was analysed by thin layer chromatography, HPLC, and mass spectroscopy methods. F1, F2 and F4 were successfully synthesized and each of them was detected at 1490.0, 1874.8 and 1881.9 amu, respectively. However, F1 was not possible to purify because of its insolubility in various solvents.
\end{abstract}

Keywords: bird flu, epitope, precursor, solid phase peptide synthesis, universal influenza vaccine

\begin{abstract}
ABSTRAK
Vaksin konvensional yang benar-benar efektif untuk menghentikan penyebaran penyakit flu burung sampai saat ini belum ditemukan karena virus influenza sangat mudah bermutasi. Meskipun terus mengalami mutasi, yang menyebabkan urutan asam amino protein-proteinnya berubah, virus influenza memiliki domain luar protein M2 yang bersifat lestari, terutama M2e(2-16) (SLLTEVETPIRNEW). Penggunaan epitop lestari M2e(2-16) dalam vaksin berbasis epitop berpotensi menghasilkan vaksin influenza universal. Pada perancangan vaksin berbasis epitop, M2e(2-16) perlu digabungkan dengan epitop sel T penolong, yaitu P25, yang disebut M2e(2-16)-K-P25 (SLLTEVETPIRNEWGKKKLIPNASLIENCTKAEL). M2e(216)-K-P25 disintesis dengan strategi sintesis konvergen peptida fase padat karena ukuran sekuennya yang cukup panjang. Pada strategi ini, empat peptida prekursor M2e(2-16)-K-P25; SLLTEVETP (F1), IRNEWGK (F2), KLIPNASLI (F3), dan ENCTKAEL (F4); disintesis terlebih dahulu. Setelah peptida-peptida prekursornya yang masih bergugus pelindung siap, reaksi penggandengan dilakukan untuk memperoleh M2e(2-16)-K-P25. Pada penelitian sebelumnya, F3 berhasil diperoleh dengan kemurnian tinggi melalui metode sintesis peptida fase padat Fmoc/tBu. Pada penelitian kali ini, tiga prekursor lainnya; F1, F2, dan F4; disintesis dengan metode serupa. Setiap peptida dianalisis dengan metode kromatografi lapis tipis, HPLC, dan spektroskopi massa. Peptida F1, F2, dan F4 berhasil disintesis dan masing-masing terdeteksi pada spektra massa
\end{abstract}

*Telp: +628156111156

Email: t_subroto@unpad.ac.id 
di m/z 1490,0; 1874,8; dan 1881,9 sma. Peptida F2 dan F4 berhasil dimurnikan dengan kromatografi kolom silika G60. Namun, peptida F1 tidak memungkinkan untuk dimurnikan karena ketidaklarutannya dalam berbagai macam pelarut.

Kata Kunci: epitop, flu burung, prekursor, sintesis peptida fase padat, vaksin influenza universal

\section{PENDAHULUAN}

Vaksin konvensional yang benar-benar efektif, berupa virus influenza yang dilemahkan, untuk menghentikan penyebaran flu burung sampai saat ini belum ditemukan. Hal ini karena virus influenza yang bersirkulasi ternyata terus-menerus mengalami mutasi. Mutasi tersebut menyebabkan perubahan pada protein permukaan virus influenza, yaitu hemaglutinin dan neuraminidase, yang merupakan target respons imun. Akibatnya varian virus influenza tidak lagi dikenali oleh sistem imun yang sebelumnya pernah terpapar flu (Carrat \& Flahault 2007).

Saat ini, upaya pengembangan vaksin influenza mengarah pada protein matriks 2 (M2). Protein ini merupakan saluran proton yang diperlukan dalam pengasaman virus sehingga memungkinkan terjadinya replikasi (Betakova 2007). Domain luar protein M2 (M2e), terdiri atas 24 urutan asam amino (SLLTEVETPIRNEWGCRCNDSSD), bersifat lestari (Fiers et al. 2004) terutama SLLTEVETPIRNEWG (M2e(2-16)). Bagian sekuen ini dikenali oleh antibodi monoklonal yang menghambat replikasi virus influenza A pada sel model MDCK (Pejoski et al. 2010). Kelestarian M2e ini memungkinkan dirancangnya suatu vaksin influenza universal (Wang et al. 2008).

Selain vaksin konvensional, pengembangan vaksin berdasarkan epitop, yang merupakan bagian antigen minimal yang dapat menginduksi sistem imun, telah menarik perhatian para peneliti (Jackson et al. 2006). Keunggulan vaksin berbasis epitop meliputi tingginya spesifisitas dalam membangkitkan respons imun, kemurnian tinggi, kapasitas produksi yang besar, dan biaya produksi yang efektif (Toth et al. 2008). Vaksin berbasis epitop juga dapat dirancang untuk merangsang respons imun pada epitop lestari sehingga dapat dijadikan vaksin universal (Sette \& Fikes 2003). Vaksin berbasis epitop tersebut lebih aman karena tidak mengandung mikroba hidup yang dapat memperbanyak diri dan menyebabkan penyakit, serta mengurangi terjadinya autoimun (Flower 2008).
Penggunaan epitop lestari M2e(2-16) sebagai epitop target sel B berpotensi menghasilkan vaksin influenza universal yang dapat melindungi dari berbagai varian influenza, meskipun virus ini rentan mengalami mutasi (Wang et al. 2008). Jackson et al. 2006 mengungkapkan bahwa vaksin berbasis epitop umumnya mengandung epitop target sel B atau sel T sitotoksik, dan epitop sel T penolong (Jackson et al. 2006) sehingga epitop M2e(2-16) dalam perancangan vaksin berbasis epitop perlu digabungkan dengan epitop sel $\mathrm{T}$ penolong yang pada penelitian ini digunakan epitop P25. Epitop P25 dengan urutan KLIPNASLIENCTKAEL merupakan protein fusi yang berasal dari virus penyakit pada anjing. Epitop ini telah banyak digunakan sebagai epitop sel $\mathrm{T}$ penolong karena mudah dikenali oleh sel $\mathrm{T}$ penolong dan mengaktivasi baik sistem imun selular maupun humoral untuk menghadapi serangan patogen (Alphs et al. 2008; Ghosh et al. 2001; Jackson et al. 2004).

Pada perancangan vaksin berbasis epitop, M2e(2-16) perlu digabungkan dengan epitop sel $\mathrm{T}$ penolong, yaitu P25. Hal ini bertujuan untuk meningkatkan respons kekebalan yang dihasilkan terhadap epitop M2e(2-16). Penggabungan kedua epitop selanjutnya disebut M2e(2-16)-K-P25 (SLLTEVETPIRNEWGKKKLIPNASLI ENCTKAEL). Sintesis konvergen peptida fase padat dipilih untuk menghasilkan M2e(2-16)-K-P25, karena panjagnnya ukuran sekuen epitop gabungan tersebut. Penggunaan strategi sinstesis konvergen (Barlos \& Gatos 1999) diharapkan dapat meningkatkan keberhasilkan sintesis M2e(2-16)-K-P25.

Pada penelitian ini telah disintesis tiga peptida bergugus pelindung; SLLTEVETP(F1), IRNEWGK (F2), dan ENCTKAEL (F4); yang merupakan prekursor M2e(2-16)-K-P25. Pemilihan segmentasi prekursor didasarkan pada kriteria prekursor sintesis konvergen peptida fase padat (Barlos \& Gatos 1999), seperti pemilihan prekursor dengan asam amino prolin pada ujung-C dan 
kereaktifan ujung-C dan $-\mathrm{N}$ setiap peptida prekursor. Peptida-peptida tersebut disintesis melalui metode sintesis peptida fase padat Fmoc/tBu dengan metode penggandengan karbodiimida (Chan \& White 2000). Pada proses sintesis zat tambahan oksima digunakan sebagai penekan reaksi samping yang mungkin terjadi (Subirós-Funosas et al. 2009). Peptida-peptida yang dihasilkan diukur dengan spektroskopi massa untuk mengonfirmasi sekuennya berdasarkan bobot molekul.

\section{BAHAN DAN METODE}

Sintesis Peptida Bergugus Pelindung. Sintesis peptida fase padat Fmoc/tBu setiap fragmen peptida bergugus pelindung; SLLTEVET (F1), IRNEWGK (F2), dan ENCTKAEL (F4); mengacu pada protokol sintesis peptida (Chan \& White 2000) dengan modifikasi. Peptida disintesis pada fase pendukung padat (resin) 2-klorotritil klorida. Gugus pelindung Fmoc pada asam amino, yang telah terikat pada resin, dilepaskan sebelum reaksi penggandengan asam amino menggunakan piperidin $25 \%$ dalam DMF atau DBU/piperidin/DMF (1:1:48). Keberhasilan reaksi pelepasan gugus Fmoc dipantau dengan berubahnya warna butiran resin menjadi biru dan coklat pada uji Kaiser dan kloranil atau tidak munculnya pendaran pada uji kromatografi lapis tipis (KLT) di bawah sinar UV panjang gelombang $254 \mathrm{~nm}$. Reaksi penggandengan asam amino bergugus pelindung menggunakan pendekatan karbodiimida dengan oksima sebagai zat tambahan (Hardianto et al. 2011; Subirós-Funosas et al. 2009). Lengkapnya reaksi ini ditandai melalui tidak berubahnya warna butiran resin pada uji Kaiser dan kloranil atau munculnya pendaran pada uji KLT di bawah sinar UV pada panjang gelombang $254 \mathrm{~nm}$. Reaksi pelepasan gugus pelindung tidak dilakukan pada residu asam amino ujung$\mathrm{N}$. Setiap peptida bergugus pelindung dilepaskan dari resin menggunakan TFE/ DCM (2:8).

Analisis Peptida Bergugus Pelindung. Peptida bergugus pelindung dikarakterisasi dengan metode kromatografi lapis tipis dan spektroskopi massa (ESI-MS). Kromatografi lapis tipis dilakukan pada fase diam silika $\mathrm{GF}_{254}$ dan C-18. Peptida yang belum murni dimurnikan dengan kromatografi kolom $\mathrm{G}_{60}$ baik secara gradien maupun isokratik. Eluen yang digunakan adalah komposisi campuran pelarut kloroform dan metanol dengan penambahan asam asetat glasial sebanyak $1 \%(\mathrm{v} / \mathrm{v})$. Selanjutnya, peptida yang telah dimurnikan dianalisis dengan metode HPLC pada kolom C-8 agilent dan spektroskopi massa (ESI-MS).

\section{HASIL DAN PEMBAHASAN}

Sintesis Peptida Bergugus Pelindung. Setiap peptida prekursor M2e(2-16)-K-P25 disintesis dengan metode sintesis peptida fase padat Fmoc/tBu. Pada metode ini, asam amino disusun pada fase padat atau resin yang memiliki gugus aktif. Jenis resin yang digunakan pada penelitian ini adalah resin 2-klorotritil klorida. Penggunaan resin ini memungkinkan peptida dapat dilepaskan dari resin secara selektif, dengan tetap mempertahankan gugus pelindung rantai samping pada setiap residu asam amino. Penyusunan peptida pertama kali dilakukan dengan mengikatkan asam amino ujung-C dengan resin pada kondisi basa melalui reaksi SN2 (Chan \& White 2000).

Reaksi penggandengan selanjutnya bergerak dari ujung-C ke -N. Arah penyusunan ini dipandang sebagai cara yang lebih baik dalam meminimalkan reaksi samping dibandingkan arah sebaliknya (Albericio 2004). Selain penggunaan karbodiimida sebagai zat aktifnya, reaksi penggandengan juga memakai zat tambahan oksima dalam proses reaksinya. Zat oksima berfungsi menekan reaksi rasemisasi dan memiliki efisiensi kopling lebih tinggi (Subirós-Funosas et al. 2009).

Sebelum setiap reaksi penggandengan dilakukan, gugus pelindung Fmoc pada gugus alfa amino perlu dilepaskan. Reaksi pelepasan ini dilakukan dengan menambahkan larutan piperidin dalam DMF. Piperidin bertindak sebagai basa meruah yang mengatalisis reaksi pelepasan gugus Fmoc melalui pengambilan ion hidrogen. Selain itu, piperidin juga berfungsi sebagai penetral zat reaktif dibenzofulven yang merupakan hasil penguraian gugus Fmoc (Chan \& White 2000).

Pada setiap tahap penggandengan asam amino dan pelepasan gugus pelindung Fmoc, uji Kaiser pada resin dilakukan untuk mengecek masih adanya gugus amino bebas. Reaksi yang terjadi pada pengujian Kaiser adalah reaksi dengan ninhidrin dengan gugus amino bebas yang menghasilkan warna biru. Bila reaksi penggandengan 
berhasil, maka uji ini memberi hasil negatif (tidak ada lagi gugus amino bebas), yang ditandai dengan tidak berubahnya warna resin (Gambar 1 (a)). Uji Kaiser memberikan hasil positif berupa berubahnya warna resin menjadi biru tua pada reaksi pelepasan gugus pelindung. Namun, untuk beberapa asam amino (antara lain asparagin) uji Kaiser tidak cukup sensitif sehingga perlu dilakukan uji kloranil yang lebih sensitif (Chan \& White 2000). Gambar 1 (c) merupakan hasil pengujian kloranil pada resin yang telah dilepas gugus pelindungnya secara sempurna .

\section{Karakterisasi dan Pemurnian Peptida Bergugus}

Pelindung. Hasil karakterisasi dengan menggunakan spektroskopi massa (ESI-MS) menunjukkan keberhasilan sintesis tiga peptida prekursor bergugus pelindung, yaitu F1, F2, dan F3. Masing-masing peptida ditunjukkan oleh puncak spektrum massa dengan m/z 1490,0; 1874,9; 1881.9 sma pada Gambar 2. Namun, peptida-peptida tersebut tidak diperoleh dalam keadaan murni, cukup banyak puncak yang terlihat pada setiap spektra massa fragmen peptida. Analisis ketiga fragmen peptida menggunakan kromatografi lapis tipis (Gambar 3), dengan beberapa eluen baik fase normal maupun terbalik (C-18), juga menunjukkan ketiga fragmen tidak murni, sehingga dilakukan metode pemisahan dengan kromatografi kolom.

Fragmen peptida F1 memiliki kelarutan yang buruk. Fragmen ini tidak larut dalam metanol, kloroform, DCM, DMF, dan bahkan DMSO sekalipun. Buruknya kelarutan peptida bergugus pelindung merupakan masalah yang seringkali ditemui pada sintesis konvergen peptida fase padat (Narita et al. 1984). Penurunan kelarutan peptida bertambah seiring dengan semakin besarnya ukuran peptida bergugus pelindung dan jumlah gugus aktif pada rantai samping. Masalah ini biasanya muncul karena molekul-molekul peptida bergugus pelindung bergabung menyerupai struktur lembar beta protein. Modifikasi struktur peptida, dengan mengganti jenis gugus pelindung asam amino yang digunakan, adalah salah satu jalan untuk menurunkan potensi terbentuknya struktur tersebut (Gairí et al. 1995).

Pengukuran spektrum massa fragmen F1 dilakukan dengan menggunakan metanol sebagai pelarutnya. Diduga, sifat kelarutan fragmen F1 di dalam metanol yang sangat buruk mengakibatkan hanya sejumlah kecil fragmen F1 yang terlarut dan terukur oleh spektrometer massa. Sementara itu pengotor yang jumlahnya kecil, jika kelarutannya lebih besar dari fragmen F1 maka akan terukur menyamai atau lebih besar pada spektrometer massa. Dugaan ini memberikan salah satu alasan mengapa begitu banyak puncak pengotor pada spektrum massa yang tingginya menyamai puncak fragmen $\mathrm{F} 1$.

Fragmen F2 dan F4 dengan sifat kelarutan yang baik memungkinkan keduanya untuk dimurnikan. Kedua peptida dimurnikan melalui kolom kromatografi silika $\mathrm{G}_{60} 70-230$ mesh dengan sistem pelarut gradien. Sistem pelarut dimulai

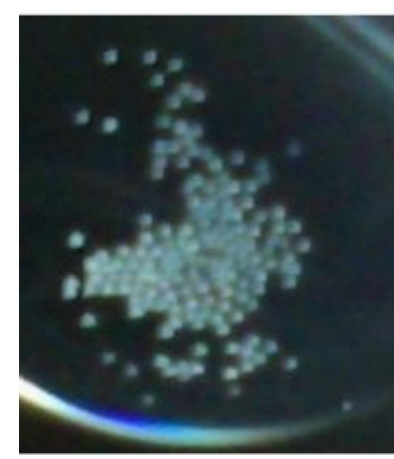

(a)

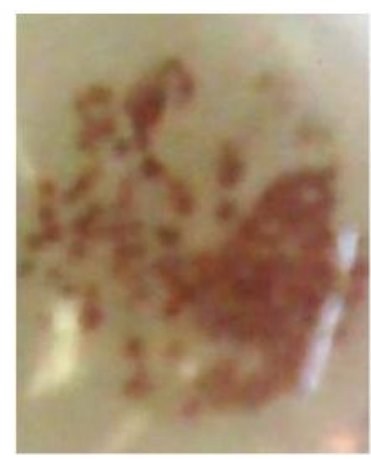

(b)

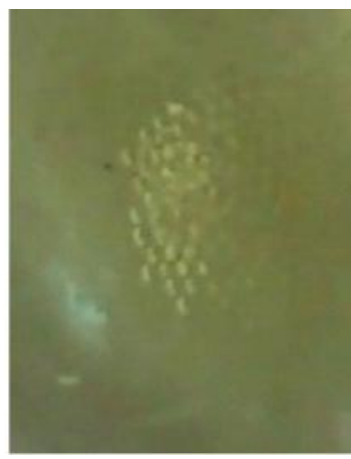

(c)

Gambar 1 Uji kualitatif asam amino, uji Kaiser dan kloranil, yang diterapkan pada hasil reaksi penggandengan dan pelepasan gugus Fmoc. (a) Hasil negatif uji Kaiser (tidak terjadinya perubahan warna) menunjukkan reaksi penggandengan telah berhasil. (b) Hasil positif uji kloranil (terbentuknya warna coklat dari asam amino bebas) menunjukkan gugus pelindung Fmoc telah terlepas. (c) Hasil negatif uji kloranil (tidak terbentuknya warna coklat dari asam amino bebas) mengindikasikan penggandengan telah berhasil. 


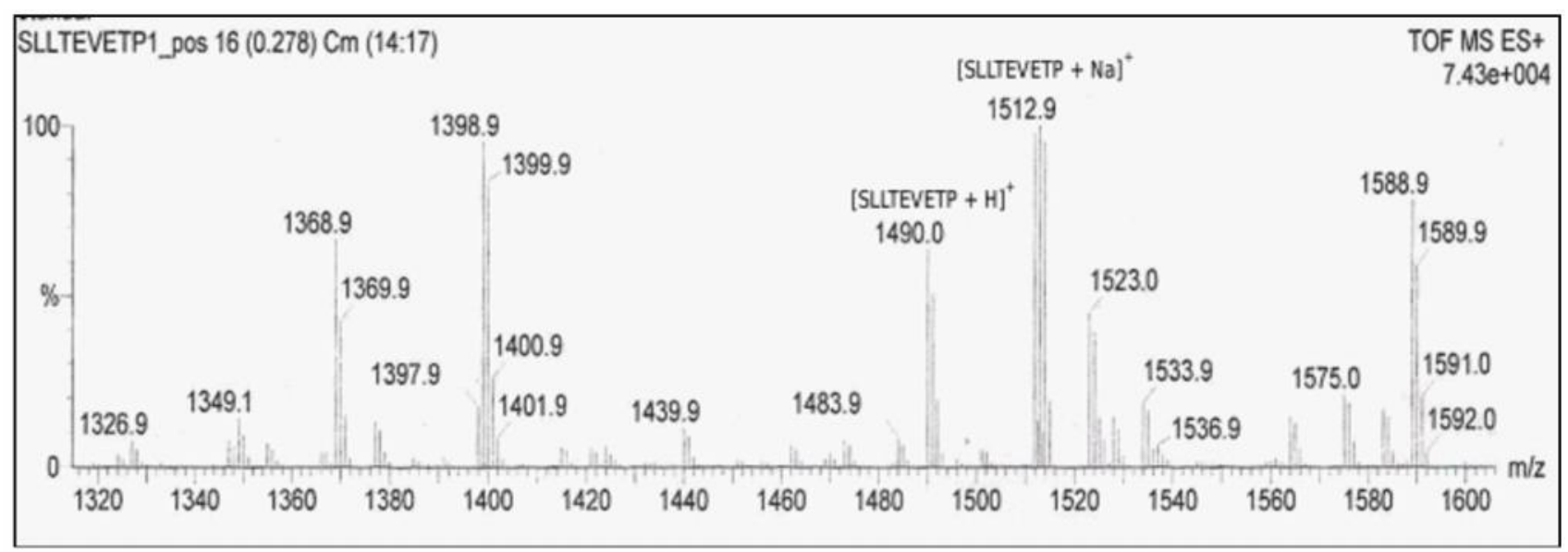

(a)

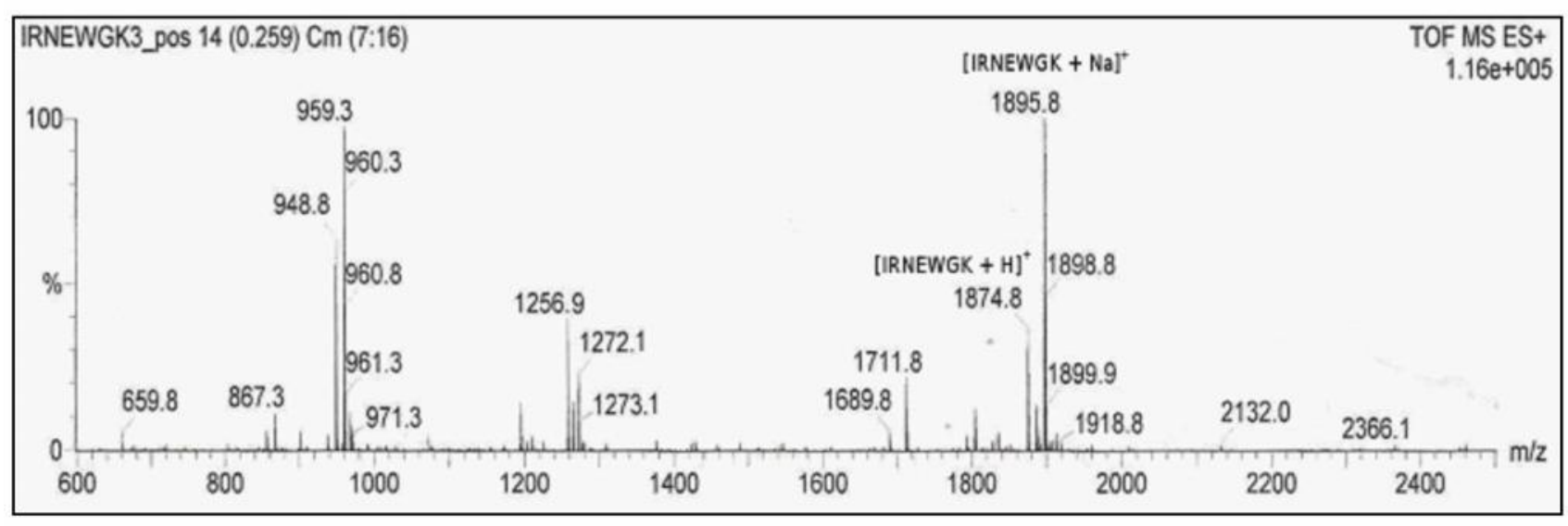

(b)

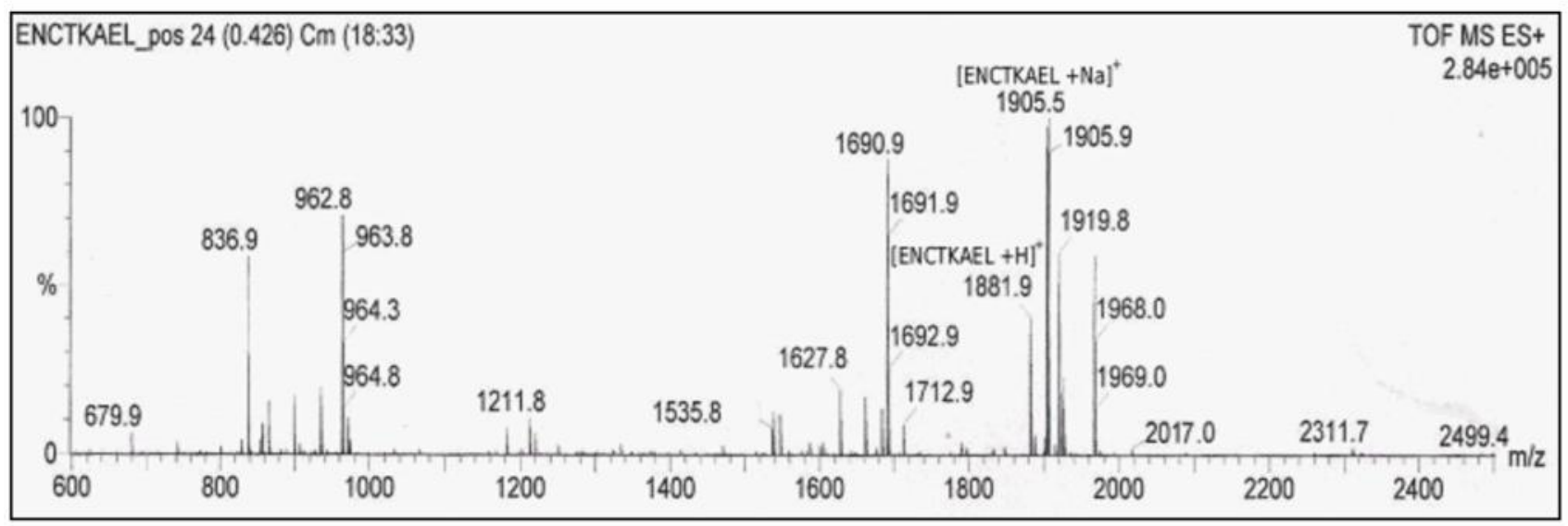

(c)

Gambar 2 Spektra massa fragmen peptida F1, F2, dan F4 yang telah disintesis. (a) Fragmen peptida F1 diwakili oleh molekul ion [SLLTEVETP + H] ${ }^{+}$dan [SLLTEVETP + Na] ${ }^{+}$pada m/z 1490,0 dan 1512,9 sma. (b) Fragmen peptida F2 diwakili oleh molekul ion [IRNEWGK + H] $]^{+}$dan [IRNEWGK + Na] ${ }^{+}$pada m/z 1874,8 dan 1895,8 sma. (c) Fragmen peptida F4 diwakili oleh molekul ion. [ENCTKAEL + H] ${ }^{+}$dan [ENCTKAEL + Na] ${ }^{+}$pada m/z 1881,9 dan 1905,5 sma. Pada spektra massa setiap fragmen dapat terlihat cukup banyak puncak, yang menunjukkan peptida diperoleh tidak dalam keadaan murni. 


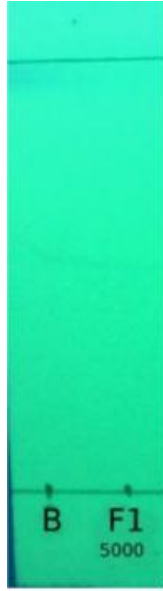

(a)

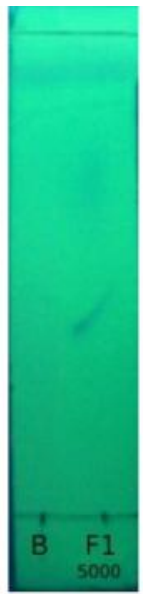

(b)

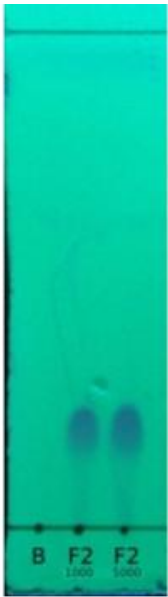

(c)

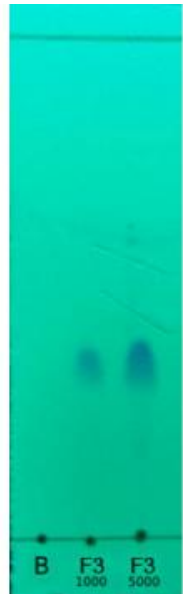

(d)

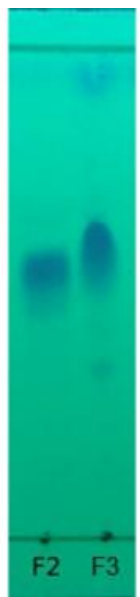

(e)

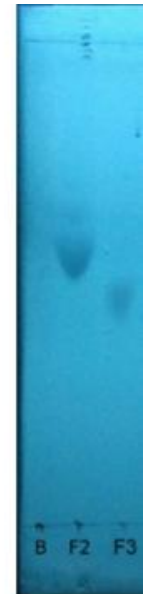

(f)

Gambar 3 Kromatogram lapis tipis fragmen peptida F1, F2, dan F3. (a) dan (b) merupakan kromatogram fragmen peptida F1, yang masing-masing ditambahkan ke dalam metanol dan kloroform $(5 \mathrm{mg} / \mathrm{mL})$ sebagai pelarutnya, dengan eluen kloroform/metanol/asam asetat (90:8:2) pada fase diam silika $\mathrm{GF}_{254}$. Fragmen peptida F1 yang ditambahkan metanol tidak menunjukkan noda apapun pada kromatogram (a), yang menunjukkan amat kecilnya. kelarutan fragmen ini dalam metanol sehingga tidak dapat terdeteksi menggunakan kromatografi lapis tipis. Sedangkan pada kromatogram (b) muncul dua noda tipis, yang menunjukkan fragmen peptida F1 sedikit larut dalam kloroform. Kromatogram (c) dan (d), masing-masing menunjukkan kromatogram lapis tipis fragmen peptida F2 dan F4 pada konsentrasi 5000 ppm yang dielusi dengan DCM/metanol/asam asetat (96:3:1). Kromatogram (e) dan (f) menunjukkan bahwa fragmen peptida F2 dan F4 tidak dalam keadaan murni. Kromatogram (e) dan (f) masing-masing pada fase diam silika GF ${ }_{254}$ dan C-18 yang dielusi dengan kloroform/metanol/asam asetat (93:6:1) dan metanol. Seluruh kromatogram dipendarkan di bawah sinar UV $254 \mathrm{~nm}$.

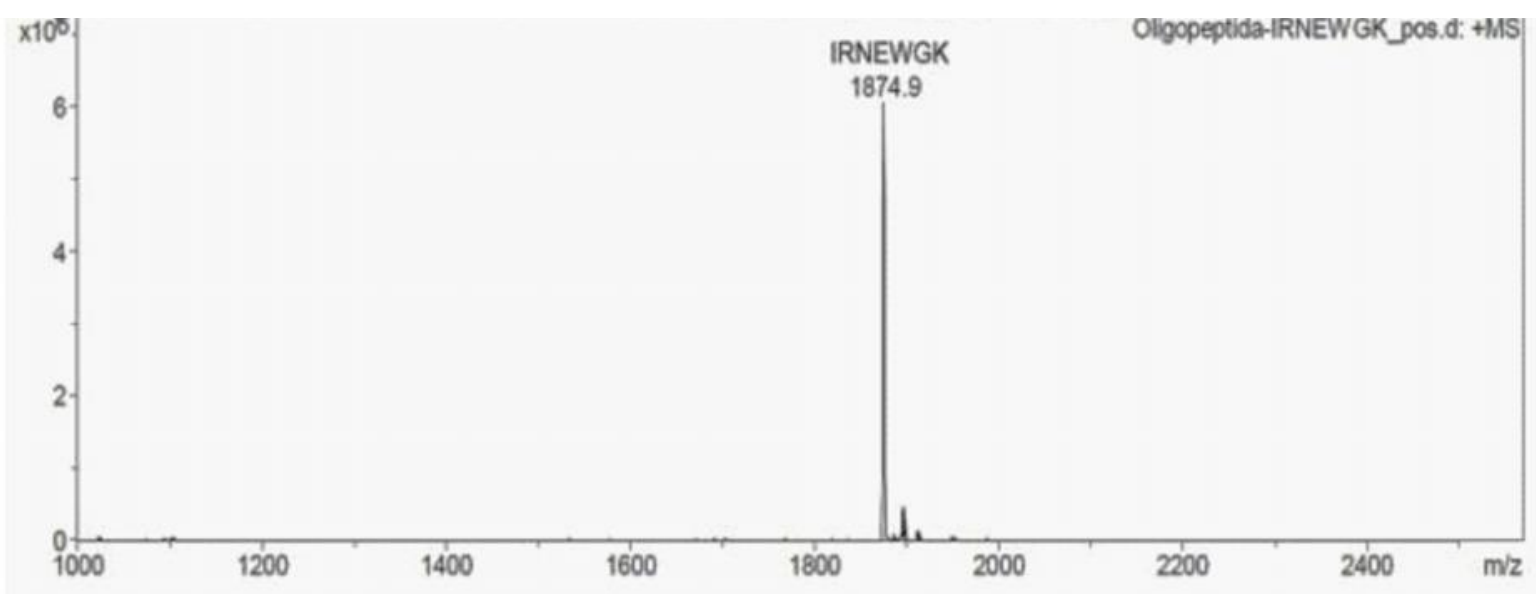

(a)

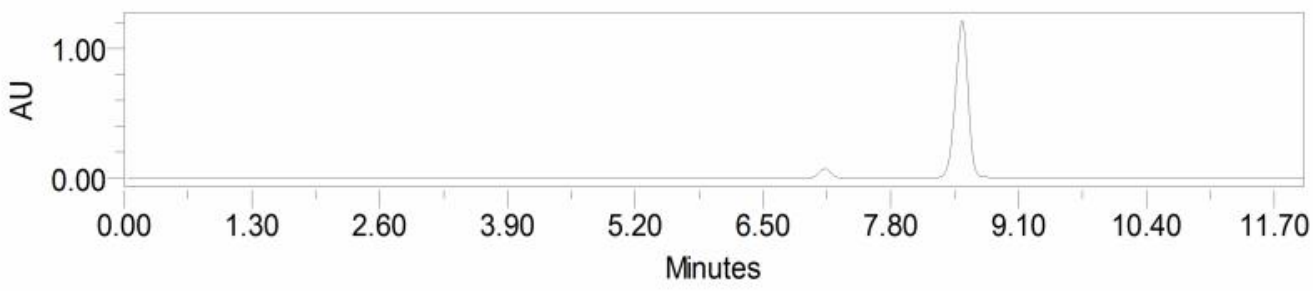

(b) 


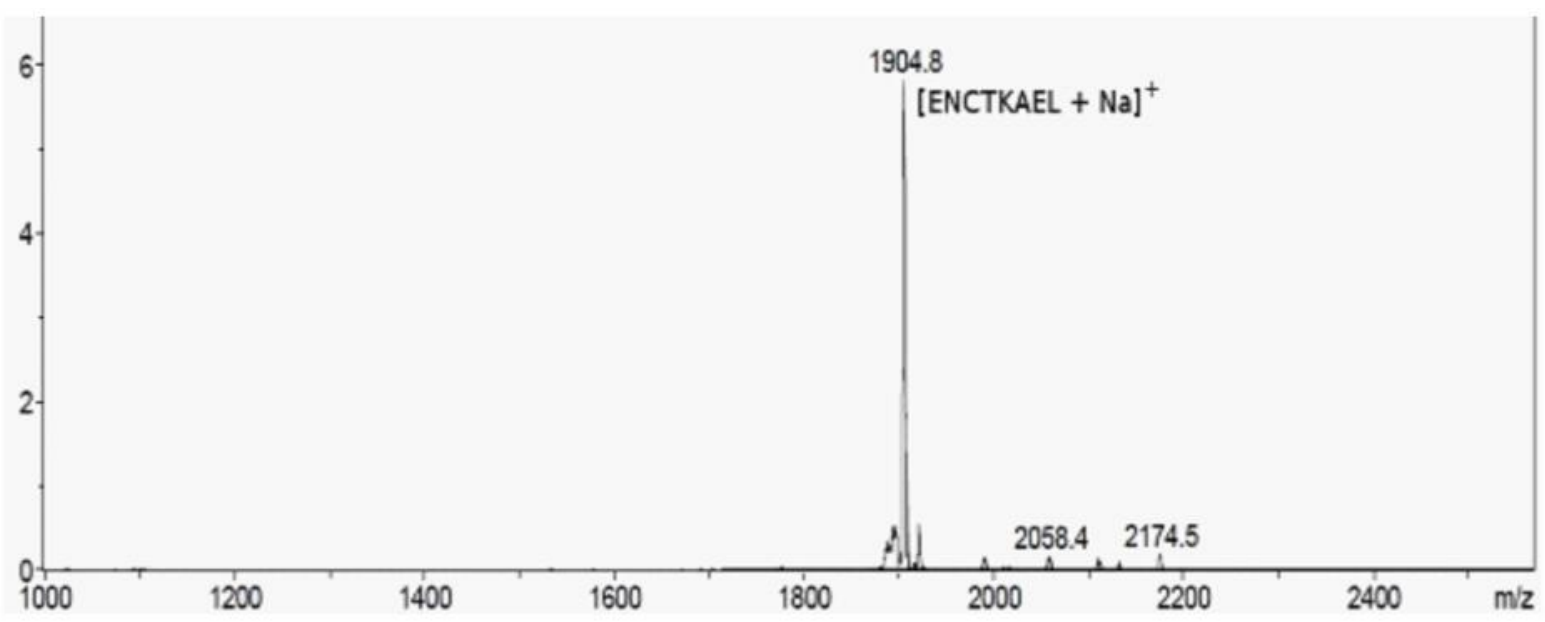

(c)

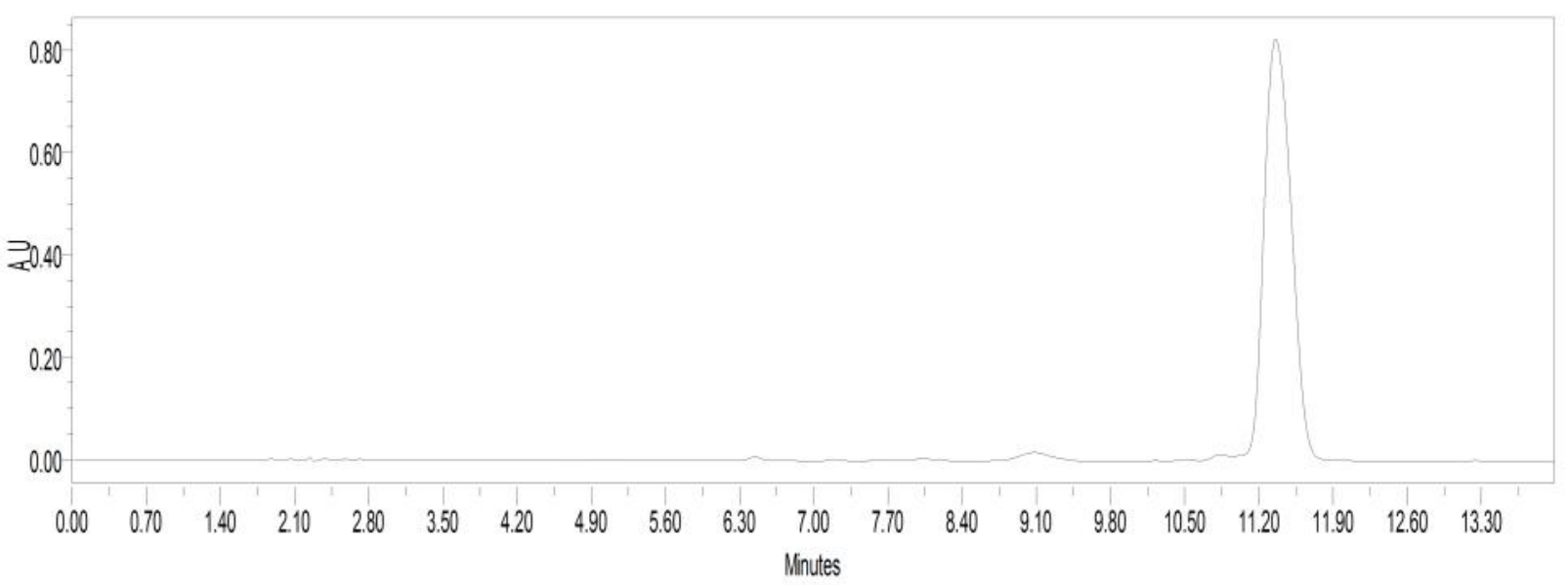

(d)

Gambar 4 Spektrum massa dan kromatogram HPLC peptida F2 dan F4 yang telah dimurnikan. (a) Spektrum massa dan (b) kromatogram HPLC peptida F2 yang telah dimurnikan menunjukkan bahwa peptida F2, yang terdeteksi pada m/z 1874,9 sma, diperoleh dengan kemurnian yang lebih tinggi. (c) Sampel hasil pemurnian peptida F3 menunjukkan puncak pada m/z 1904,8 sma yang merupakan ion molekul [F4 + Na] ${ }^{+}$. (d) Kromatogram HPLC setelah pemurnian memperkuat bahwa peptida ini telah diperoleh dengan kemurnian tinggi.Kromatografi dilakukan pada kolom C-8 Agilent menggunakan eluen gradien asetonitril: air-5\% TFA (8:2) s.d. 5\% TFA-air selama 12 menit pada laju alir $1 \mathrm{~mL} /$ menit dan panjang gelombang detektor diset pada panjang gelombang $265 \mathrm{~nm}$.

dari kloroform/metanol/asam asetat (97:2:1) dengan kenaikan volume metanol $0,5 \%$ secara berangsur-angsur sampai kloroform/metanol/ asam asetat (91:8:1). Fragmen F2 diperoleh dengan rendemen sebanyak $18 \%$. Spektrum massa dan kromatogram HPLC yang diperlihatkan pada Gambar 4 menunjukkan peptida ini telah murni. Pada spektrum massa fragmen peptida F2 dideteksi sebagai ion molekul $[\mathrm{F} 2+\mathrm{H}]^{+}$pada m/z 1874,9 sma. Sementara itu, fragmen peptida $\mathrm{F} 4$ yang telah dimurnikan menunjukkan nilai m/z 1904,8 sma, pada spektrum massa, yang diduga kuat merupakan ion molekul $[\mathrm{F} 4+\mathrm{Na}]^{+}$. Spektrum massa dan kromatogram HPLC fragmen F4 memperlihatkan bahwa fragmen peptida bergugus pelindung ini telah berhasil dimurnikan.

Hasil sintesis fragmen F1, F2, dan F4 cukup heterogen, tidak seperti F3 yang diperoleh dalam keadaan murni setelah dilepaskan dari resin 2-klorotritil. Komposisi urutan asam amino diduga berpengaruh terhadap baiknya hasil sintesis. F3, dengan urutan asam amino KLIPNASLI, hanya memiliki setidaknya tiga residu asam amino bergugus rantai samping yang reaktif yaitu lisin $(\mathrm{K})$, asparagin $(\mathrm{N})$, dan serin (S). Sedangkan F1, F2, dan F4 masing-masing 
memiliki lima, enam, dan lima gugus rantai samping yang reaktif dari sembilan, delapan, dan tujuh urutan asam amino.

\section{SIMPULAN}

Peptida-peptida bergugus pelindung penyusun epitop M2e(2-16)-K-P25; SLLTEVET (F1), IRNEWGK (F2), dan ENCTKAEL (F3); telah berhasil dibuat dengan sintesis peptida fase padat Fmoc/tBu menggunakan metode penggandengan karbodiimida dengan zat tambahan oksima yang masing-masing terdeteksi pada m/z 1490,0; 1874,9; dan 1881,9 sma. Peptida M2e(2-16)-K bergugus pelindung sebaiknya dibuat secara kontinu menggunakan sintesis peptida fase padat Fmoc/tBu bertahap, mengingat fragmen F1 tidak memiliki kelarutan yang baik di berbagai pelarut.

\section{UCAPAN TERIMA KASIH}

Terima kasih kepada Kementrian Riset dan Teknologi Republik Indonesia atas bantuan dana untuk melaksanakan penelitian ini melalui Insentif Riset SINas 2012.

\section{DAFTAR PUSTAKA}

Albericio, F. 2004. Developments in peptide and amide synthesis. Curr Opin Chem Biol 8(3): 211-21.

Alphs, H.H., Gambhira, R., Karanam, B., Roberts, J.N., Jagu, S., Schiller, J.T., Zeng, W., Jackson, D.C \& Roden, R.B.S. 2008. Protection against heterologous human papillomavirus challenge by a synthetic lipopeptide vaccine containing a broadly crossneutralizing epitope of L2. Proc. Natl. Acad. Sci. U. S. A. 105, 5850-5.

Barlos, K., Gatos, D. 1999. tButyl-Based Convergent. Biopolymers 51: 266-278.

Betakova, T. 2007. M2 Protein - A Proton Channel of Influenza A Virus. Curr Pharm Des 13: 3231-3235.

Carrat, F \& Flahault, A. 2007. Influenza Vaccine: The Challenge of Antigenic Drift. Vaccine 25: 6852-62.

Chan, W.C \& White, P.D. 2000. Fmoc Solid Phase Peptide Synthesis: A Practical Approach, Molecular Biology. New York: Oxford University Press.

Fiers, W., De Filette, M., Birkett, A., Neirynck, S., Min \& Jou, W. 2004. A "Universal" Human Influenza A Vaccine. Virus Res 103: 173-6.

Flower, D.R., 2008. Bioinformatics for Vaccinology, Vaccine. John Wiley \& Sons, Ltd, Chichester, UK.
Gairí, M., Lloyd-Williams, P., Albericio, F \& Giralt, E., 1995. Convergent solid-phase peptide synthesis 12 .* Chromatographic techniques for the purification of protected peptide segments. Int. J. Pept. Protein Res 46: 119-133.

Ghosh, S., Walker, J \& Jackson, D.C., 2001. Identification of canine helper T-cell epitopes from the fusion protein of canine distemper virus. Immunology 104: 58-66.

Hardianto, A., Subroto, T \& Supratman, U., 2011. Sintesis Peptida P251-9 Bergugus Pelindung dengan Metode Sintesis Peptida Fase Padat Fmoc/tBu Menggunakan Aditif Oksima. Sains dan Terap. Kim 5: 131-139.

Jackson, D.C., Chua, B \& Zeng, W. 2006. Totally Synthetic Peptide-based Vaccines that Target Dendritic Cells and Induce Potent Antibody or CTL Responses. Int. Congr. Ser 1289: 311-315.

Jackson, D.C., Lau, Y.F., Le, T., Suhrbier, A., Deliyannis, G., Cheers, C., Smith, C., Zeng, W \& Brown, L.E., 2004. A Totally Synthetic Vaccine of Generic Structure that Targets Toll-like Receptor 2 on Dendritic Cells and Promotes Antibody or Cytotoxic T Cell Responses. Proc. Natl. Acad. Sci. U. S. A. 101, 154405. doi:10.1073/pnas.0406740101.

Narita, M., Ishikawa, K., Chen, J.Y \& Kim, Y. 1984. Prediction and improvement of protected peptide solubility in organic solvents. Int. J. Pept. Protein Res 24: 580-587.

Pejoski, D., Zeng, W., Rockman, S., Brown, L.E \& Jackson, D.C. 2010. A lipopeptide based on the M2 and HA proteins of influenza A viruses induces protective antibody. Immunol. Cell Biol 88: 605-11.

Sette, A \& Fikes, J. 2003. Epitope-based Vaccines: An Update on Epitope Identification, Vaccine Design and Delivery. Curr. Opin. Immunol 15: 461-470.

Subirós-Funosas, R., Prohens, R., Barbas, R., El-Faham, A \&Albericio, F., 2009. Oxyma: an efficient additive for peptide synthesis to replace the benzotriazolebased HOBt and HOAt with a lower risk of explosion. Chemistry 15: 9394-403.

Toth, I., Simerska, P \& Fujita, Y. 2008. Recent Advances in Design and Synthesis of Self-Adjuvanting Lipopeptide Vaccines. Int. J. Pept. Res. Ther 14: 333340.

Wang, R., Song, A., Levin, J., Dennis, D., Zhang, N.J., Yoshida, H.H., Koriazova, L., Madura, L., Shapiro, L., Matsumoto, A., Mikayama, T., Kubo, R.T., Sarawar, S., Cheroutre, H \& Kato, S., 2008. Therapeutic potential of a fully human monoclonal antibody against influenza A virus M2 protein. Antiviral Res 80: 16877 . 